\title{
Differentiation among strains and serotypes of Bacillus thuringiensis by M13 DNA fingerprinting
}

\author{
Vanya Miteva, ${ }^{*}$ Agnes Abadjieva and Rosa Grigorova \\ Institute of Microbiology, Bulgarian Academy of Sciences, 'Acad. Bonchev' 26, 1113 Sofia, Bulgaria
}

(Received 17 July 1990; revised 23 October 1990; accepted 26 October 1990)

\begin{abstract}
The inter- and intraserotypic variations of Bacillus thuringiensis were studied by M13 DNA fingerprinting. Strainspecific patterns were obtained. The degree of homology was evaluated on the basis of pairwise comparisons and calculation of similarity indexes. Some strains belonging to the same serotype showed highly similar patterns, but others differed significantly. A high degree of polymorphism was established among the serotypes. These results provide evidence that the classification of $B$. thuringiensis strains on the basis of flagellar antigens does not always adequately reflect their genetic relatedness. DNA fingerprinting could help in future numerical taxonomic analysis of this species.
\end{abstract}

\section{Introduction}

The insect pathogen Bacillus thuringiensis is classified on the basis of flagellar antigens into more than 20 serotypes (de Barjac \& Bonnefoi, 1973; Aronson et al., 1986). Usually, isolates within serotypes differ in their general biochemical characteristics, plasmid patterns, and the shape, stability and host range activity of the entomocidal crystals. Some of the serotypes are divided into subserotypes. Krywienczyk (1977) extended this classification by including crystal antigens.

The investigation of genetic relatedness within the species $B$. thuringiensis was started by DNA-DNA competition experiments (Somerville \& Jones, 1972; Kaneko et al., 1978) and concentrated later on comparison of plasmids and endotoxin genes using cloned toxin sequences as probes (Kronstad et al., 1983; Prefontaine et al., 1987). No strong correlation between flagellar and crystal serotype and endotoxin genotype has been observed. The need for a new classification system based on the degree of genetic homology has been emphasized (Luthy, 1986; Priest et al., 1988).

We recently reported the presence of hypervariable nucleotide sequences in several Gram-positive bacteria, including $B$. thuringiensis, detected by M13 DNA fingerprinting (Miteva et al., 1990). This technique, based on Southern hybridization of restriction-enzymedigested genomic DNA with a probe containing a specific repeated sequence, reveals patterns which are highly variable from one individual to another (Jeffreys et al., 1985; Vassart et al., 1987). This allows differentiation between closely related species and between individual organisms and strains (Ryskov et al., 1988). A major advantage of this technique is that the whole genome is examined. Here, we applied DNA fingerprinting with M13 DNA as a probe for studying of interand intraserotypic variations of different $B$. thuringiensis strains.

\section{Methods}

Strains. The strains of $B$. thuringiensis used are listed in Table 1. They were grown in Nutrient Broth (Difco) at $28^{\circ} \mathrm{C}$ for $16 \mathrm{~h}$.

Total DNA isolation and restriction. High-molecular-mass DNA was isolated as described previously (Miteva et al., 1990). DNA samples (10 $\mu \mathrm{g}$ ) were digested with the appropriate restriction enzyme (Boehringer or Amersham) in the reaction buffer of the supplier, using 5-10 U per $\mu \mathrm{g}$ DNA. Digestions were allowed to proceed to completion for $12-18 \mathrm{~h}$ at $37^{\circ} \mathrm{C}$. The fragments were separated by electrophoresis in $25 \mathrm{~cm}$ long $1 \%(\mathrm{w} / \mathrm{v})$ agarose gels (Sigma) at $8 \mathrm{~V} \mathrm{~cm}^{-1}$ and stained with ethidium bromide.

Hybridization. DNA from the agarose gels was blotted onto nitrocellulose filters (Hybond-C, Amersham) according to Southern (1975). Single-stranded M13mp8 DNA was labelled by the primer extension method to a specific activity of $1.0 \times 10^{-9}$ c.p.m. $\mu \mathrm{g}^{-1}$ $\left(1.5 \times 10^{7}\right.$ c.p.m. per filter $)$ using $\left[{ }^{32} \mathrm{P}\right] \mathrm{dCTP}$, sequencing primer and a commercial kit from Amersham. Hybridization was performed in $5 \times$ SSC, $5 \times$ Denhardt's solution, $0 \cdot 1 \%$ SDS, 5 mM-EDTA at $57^{\circ} \mathrm{C}$ or $51{ }^{\circ} \mathrm{C}$ for $16-20 \mathrm{~h}(\mathrm{I} \times \mathrm{SSC}$ is $0.15 \mathrm{M}-\mathrm{NaCl}, 0.015 \mathrm{M}$-sodium citrate, $\mathrm{pH} 7.0 ; 1 \times$ Denhardt's solution is $0.02 \%$ bovine serum albumin, $0.02 \%$ Ficoll, $0.02 \%$ polyvinylpyrrolidone). The filters were washed in 
Table 1. Bacillus thuringiensis strains

All the strains have been maintained as a local laboratory collection for over 15 years.

\begin{tabular}{|c|c|c|}
\hline $\begin{array}{l}\text { Subspecies and } \\
\text { strain designation }\end{array}$ & $\begin{array}{l}\text { Flagellar } \\
\text { serotype }\end{array}$ & Source* \\
\hline \multicolumn{3}{|l|}{ thuringiensis } \\
\hline B & 1 & Institut Pasteur $^{1}$ \\
\hline Berliner & 1 & $\mathrm{PPI}^{2}$ \\
\hline Steinhaus 1715 & 1 & I. R. Pendleton ${ }^{3}$ \\
\hline Leith & 1 & I. R. Pendleton \\
\hline $\mathbf{N}$ & 1 & $\begin{array}{l}\text { Local isolate (Grigorova, } \\
\text { 1964) }\end{array}$ \\
\hline 058 & 1 & Institut Pasteur \\
\hline 4058/A & 1 & I. $R$. Pendleton \\
\hline I & & $\begin{array}{l}\text { J. Y. Shethna, Bangalore, } \\
\text { India }\end{array}$ \\
\hline \multicolumn{3}{|l|}{ finitimus } \\
\hline fin-2 & 2 & H. J. Somerville 4 \\
\hline \multicolumn{3}{|l|}{ kurstaki } \\
\hline Euxoae & $3 a$ & I. R. Pendleton \\
\hline HDl & $3 \mathrm{a} 3 \mathrm{~b}$ & P. Luthy, Zürich, Switzerland \\
\hline HD1-Dipel & $3 a 3 b$ & E. Videnova, Sofia, Bulgaria \\
\hline \multicolumn{3}{|l|}{ sotto } \\
\hline T-84-A & $4 a 4 b$ & I. R. Pendleton \\
\hline \multicolumn{3}{|l|}{ kenyae } \\
\hline S-4-2 & $4 a 4 c$ & H. J. Somerville \\
\hline Rhodesia & $4 a 4 c$ & I. R. Pendleton \\
\hline \multicolumn{3}{|l|}{ galleriae } \\
\hline Slough & 5 & I. R. Pendleton \\
\hline Galleria & $5 \mathrm{a} 5 \mathrm{~b}$ & PPI \\
\hline Beira & 5 & I. R. Pendleton \\
\hline \multicolumn{3}{|l|}{ subtoxicus } \\
\hline SubVIA & 6 & H. J. Somerville \\
\hline \multicolumn{3}{|l|}{ entomocidus } \\
\hline EntVIB & $6 \mathrm{a} 6 \mathrm{~b}$ & H. J. Somerville \\
\hline Limassol & 6 & I. R. Pendleton \\
\hline \multicolumn{3}{|l|}{ aizawai } \\
\hline ai-VII3 & 7 & H. J. Somerville \\
\hline $1 \mathrm{HA}$ VII & 7 & I. R. Pendleton \\
\hline Pill 122 & 7 & I. R. Pendleton \\
\hline \multicolumn{3}{|l|}{ morrisoni } \\
\hline $8 \mathrm{~m}$ & $8 \mathrm{a} 8 \mathrm{~b}$ & H. J. Somerville \\
\hline morrisoni & $8 \mathrm{a} 8 \mathrm{~b}$ & Institut Pasteur \\
\hline \multicolumn{3}{|l|}{ israelensis } \\
\hline $\mathrm{H} 14$ & 14 & Institut Pasteur \\
\hline H14-99 & 14 & $\begin{array}{l}\text { Acrystalliferous, plasmidless } \\
\text { mutant (Miteva et al., 1986) }\end{array}$ \\
\hline
\end{tabular}

* 1, Institut Pasteur, Paris, France; 2, Plant Protection Institute, Leningrad, USSR; 3, I. R. Pendleton, University of Glasgow, UK; 4, H. J. Somerville, Shell Research, Sittingbourne, UK.

$2 \times \mathrm{SSC}, 0 \cdot 1 \% \mathrm{SDS}$ for $30 \mathrm{~min}$ at the same temperature as used for hybridization and exposed to X-ray films at $-70^{\circ} \mathrm{C}$.

Data analysis. The approach of Jeffreys et al. (1985) and Nybom et al. (1990) was used. In the comparative analysis, several autoradiographs of different intensity were used to evaluate the number and intensity of the bands. The similarity index, $D$, was calculated for each pair of patterns $\mathrm{A}$ and $\mathrm{B}$ according to the equation $D_{\mathrm{AB}}=2 \times$ no. of shared fragments/(no. of fragments in $A+$ no. of fragments in $B$ ). It reflects the probability that a fragment in $\mathrm{A}$ is also present in $\mathrm{B}$. The probability that $\mathrm{A}$ and $\mathrm{B}$ share all common fragments $\left(P_{\mathrm{C}}\right)$ was calculated as the mean $D_{\mathrm{AB}}$ for a given serotype raised to the power of the mean number of fragments per genome. Standard deviations were calculated where appropriate.

Reproducibility of the method. To obtain reproducible band patterns it was important to use high-molecular-mass DNA and to achieve total cleavage and perfect resolution of the fragments in the agarose gels. The stability of the patterns was proved by repeating the whole procedure after subcultivation (five or more passages on agar). Two or more blots from each digestion were prepared and analysed. The original $E c o$ RI and $H a e I I I+E c o R I$ genomic fingerprints were found to be maintained in all cases.

\section{Results and Discussion}

Twenty-eight strains belonging to thirteen serotypes and subserotypes were studied (Table 1). Total DNA preparations were digested to completion with one or two restriction endonucleases. After blotting and hybridization with radioactively labelled M13 DNA, the profiles were compared pairwise and the similarity index, $D$, was calculated. Taking into consideration our previous observations that Gram-positive micro-organisms need less stringent conditions for hybridization than Gram-negative ones (Miteva et al., 1990) we performed the hybridization of each filter at $57^{\circ} \mathrm{C}$ and at $51^{\circ} \mathrm{C}$. At the lower temperature the number of informative bands was approximately doubled, hence the number of differences increased (see Fig. 3). However, for most of the strains the similarity indexes obtained at the two temperatures were quite close (Table 2). Even on the basis of the lower number of bands under higher stringency conditions the data were still sufficient to detect differences not only between serotypes but within them as well, and to give reproducible quantitative results.

We tried to find some correlation between the enzymes used and the polymorphic patterns. For this purpose restriction endonucleases recognizing a different number of nucleotides were used. Double digestions gave a larger number of bands, usually of lower intensity, than did single digestions (Fig. 1). The molecular size of the fragments obviously decreased when double digestions and enzymes recognizing four nucleotides were used (Fig. 2). The different intensity of the observed bands could be explained by the lower number and arrangement of the repeats homologous to the consensus M13 sequences in a given fragment. Usually several cleavage patterns had to be examined in order to differentiate between the strains and the serotypes. In all cases the number and distribution of the hybridization bands of a sample digested with the same enzyme or pair of enzymes reproducibly generated a unique pattern. 
Table 2. Analysis of the intraserotypic variations of EcoRI+HaeIII-digested DNA samples of B. thuringiensis under two hybridization stringency conditions

The index of similarity, $D$, is a mean of all pairwise comparisons. Data are means of the analysis of autoradiographs from two hybridization series. SD values are given in parentheses.

\begin{tabular}{|c|c|c|c|c|c|}
\hline $\begin{array}{c}\text { Serotype/ } \\
\text { no. of strains }\end{array}$ & $\begin{array}{l}\text { Hybridization } \\
\text { temp. }\left({ }^{\circ} \mathrm{C}\right)\end{array}$ & $\begin{array}{l}\text { No. of informative } \\
\text { fragments }\end{array}$ & $\begin{array}{l}\text { No. of fragments } \\
\text { per genome }\end{array}$ & $\begin{array}{l}\text { Index of } \\
\text { similarity } \\
(D)\end{array}$ & $\begin{array}{c}\text { Probability } \\
\left(P_{\mathrm{C}}\right)\end{array}$ \\
\hline \multirow[t]{2}{*}{$1 / 2$} & 57 & 24 & $6.0(1.42)$ & $0.84(0.09)$ & $3.5 \times 10^{-1}$ \\
\hline & 51 & 43 & $10.7(0.96)$ & $0.93(0.03)$ & $2 \cdot 1 \times 10^{-1}$ \\
\hline \multirow[t]{2}{*}{$3 / 3$} & 57 & 50 & $8 \cdot 3(2 \cdot 80)$ & $0.45(0.36)$ & $1.3 \times 10^{-4}$ \\
\hline & 51 & 96 & $16.0(4.40)$ & $0.45(0.70)$ & $2.8 \times 10^{-6}$ \\
\hline \multirow[t]{2}{*}{$4 / 3$} & 57 & 42 & $7.0(1.37)$ & $0.62(0.22)$ & $3.5 \times 10^{-2}$ \\
\hline & 51 & 69 & $11.5(3.56)$ & $0.57(0.24)$ & $1.5 \times 10^{-3}$ \\
\hline \multirow[t]{2}{*}{$5 / 3$} & 57 & 38 & $6.3(2.04)$ & $0.60(0.28)$ & $4.0 \times 10^{-2}$ \\
\hline & 51 & 69 & $11.5(1.52)$ & $0.62(0.24)$ & $4.1 \times 10^{-3}$ \\
\hline \multirow[t]{2}{*}{$6 / 3$} & 57 & 32 & $5 \cdot 3(1.89)$ & $0.57(0.24)$ & $5 \cdot 1 \times 10^{-2}$ \\
\hline & 51 & 70 & $11.6(0.80)$ & $0.53(0.31)$ & $6.3 \times 10^{-4}$ \\
\hline \multirow[t]{2}{*}{$7 / 3$} & 57 & 38 & $6.3(2.33)$ & $0.58(0.23)$ & $3.2 \times 10^{-2}$ \\
\hline & 51 & 86 & $14.3(4.55)$ & $0.66(0.21)$ & $2.6 \times 10^{-3}$ \\
\hline \multirow[t]{2}{*}{$8 / 2$} & 57 & 24 & $4.0(0.82)$ & $0.41(0.07)$ & $2.8 \times 10^{-2}$ \\
\hline & 51 & 55 & $9.2(0.50)$ & $0.61(0.33)$ & $1.1 \times 10^{-2}$ \\
\hline \multirow[t]{2}{*}{$14 / 2$} & 57 & 19 & $4.7(1.50)$ & $0.62(0.07)$ & $1.1 \times 10^{-1}$ \\
\hline & 51 & 33 & $8.2(0.50)$ & $0.79(0.05)$ & $1.4 \times 10^{-1}$ \\
\hline
\end{tabular}

\section{Comparison of strains within a serotype}

For this purpose, two or more strains belonging to the same serotype were studied. The indexes of similarity $(D)$ presented in Table 3 were obtained by pairwise comparisons of the strain genomes within a serotype; they showed a wide range of values (from $0 \cdot 11$ to $0 \cdot 9$ ). The mean $D$ values were also calculated for each serotype (Table 3).

The investigation of serotype 1, represented by eight strains, revealed a high level of identity. Strains B, 1715, $\mathrm{N}, 4058$, I and Leith showed identical patterns when digested with MspI + HaeIII (Fig. 1), ClaI + KpnI, or HindIII + MspI (data not shown). Only strain 058 differed significantly, which resulted in a very low index of similarity $(0 \cdot 1-0 \cdot 3)$ when this strain was compared to any of the above strains. The significant genomic variations of this strain, originating from Czechoslovakia, could be the result of a different evolutionary pathway. They also prove that the flagellar serotyping does not always correlate with the degree of genetic homology.

A detailed analysis of the serotype 1 strains B and Berliner was undertaken. Our previous results showed identical patterns for these strains (Miteva et al., 1990). Here we applied more enzymes, double restrictions and less stringent conditions. The results were still very similar after single digestions with PstI, PvuII, BglII or $B a m H I$ and with four combinations of two enzymes PvuII + HaeIII, PstI + PvuII (Fig. 2), EcoRI + HaeIII (Fig. 3, lanes 1 and 2), and EcoRI + PstI (data not shown). In all cases differences were detected in only one or two bands. The similarity index ranged from 0.75 to 0.93 (Table 3). Again no differences were found with EcoRI (Fig. 4, lanes 1 and 2). These results obviously reflect a very high genetic homology of most of the strains from serotype 1. They also show that many enzymes should be used in such cases.

In further experiments, two or three strains from each serotype were studied by pairwise comparisons (Figs 35 ). In some cases, two of the three strains showed highly similar patterns $(D 0.8-0 \cdot 9)$, while the third one differed significantly, which led to lower mean $D$ values for the whole serotype (Table 3). This did not depend on the enzyme used. The $D$ values for each serotype obtained after digestion with different restriction endonucleases were in most cases very close. It should be noted that the strains with highly homologous profiles belong to the same subserotype such as 3a3b (Fig. 3, lanes 4 and 5; Fig. 4, lanes 4 and 5; Fig. 5, lanes 2 and 3) and 4a4c (Fig. 3, lanes 7 and 8; Fig. 4, lanes 7 and 8; Fig. 5, lanes 5 and 6 ), while the strains demonstrating stronger variations came from other subserotypes ( $3 a$ and $4 a 4 b$ ) respectively (Fig. 3, lanes 3 and 6; Fig. 4, lanes 3 and 6; Fig. 5, lanes 1 and 4). This finding indicates a certain correlation between the division of strains on the basis of flagellar serotyping and the degree of their genetic homology. The results also show, however, that significant genetic variability exists among some strains within the $B$. thuringiensis serotypes.

With the aim of identifying minor genomic differences 


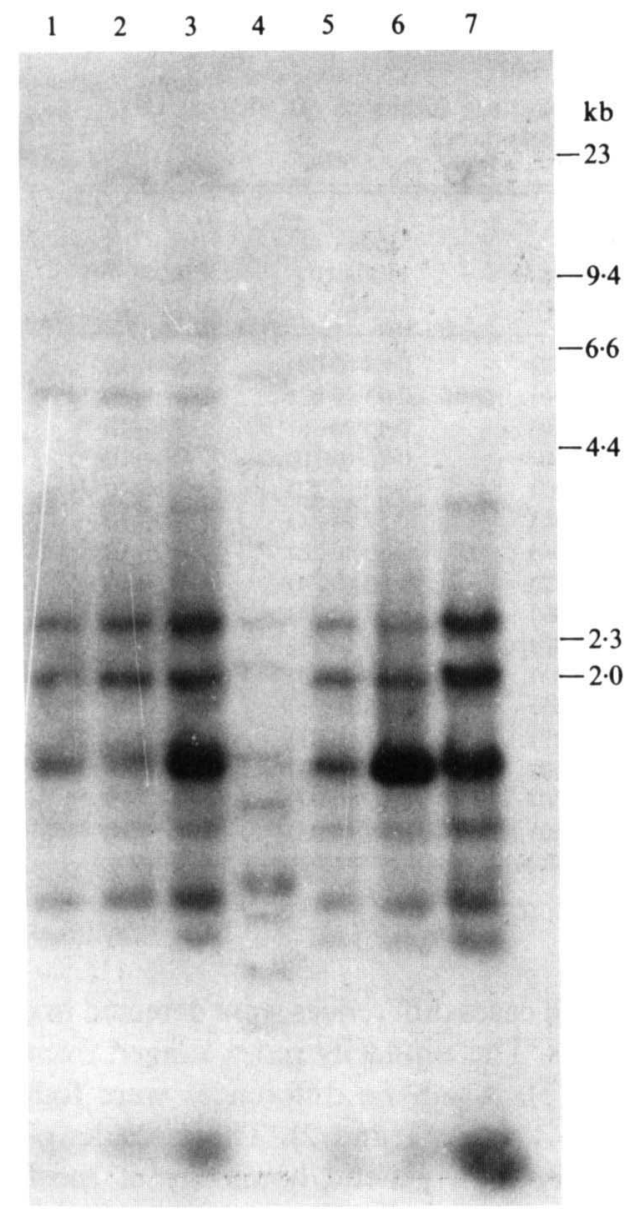

Fig. 1

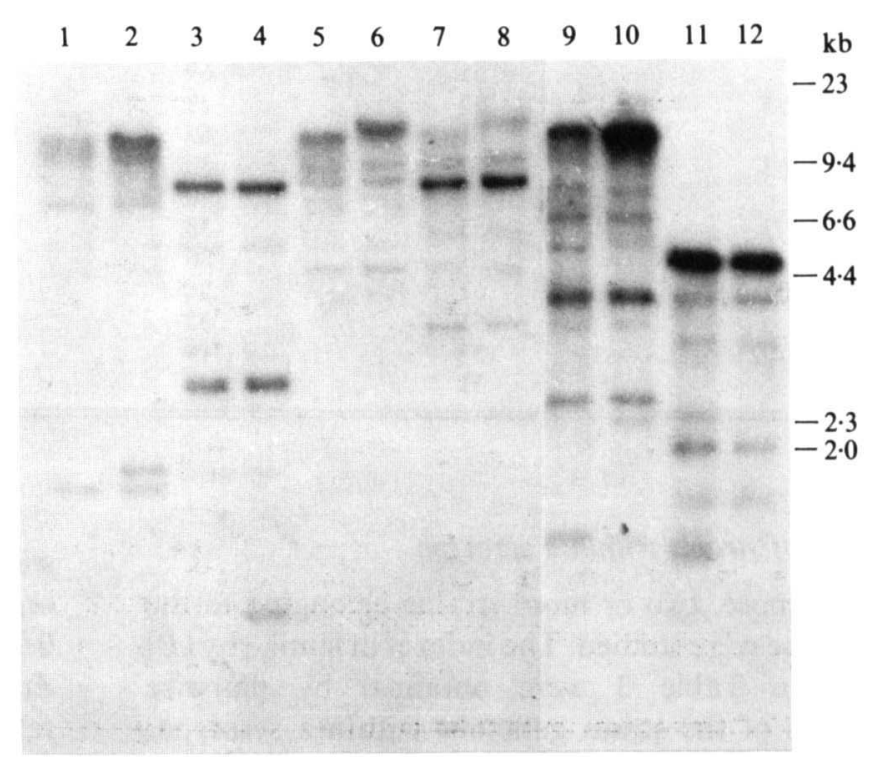

Fig. 2

Fig. 1. Southern hybridization of ${ }^{32}$ P-labelled M13 DNA to DNA from $B$. thuringiensis subsp. thuringiensis (serotype 1) after digestion with $M s p I+H a e I I I$ under low-stringency conditions $\left(51^{\circ} \mathrm{C}\right)$. Strains: lane 1, B; lane 2, Steinhaus 1715 ; lane 3, N; lane 4, 058; lane 5, 4058; lane 6, I; lane 7, Leith. The molecular sizes indicated on the right were determined from HindIII-digests of phage $\lambda$ DNA.

Fig. 2. Southern hybridization of ${ }^{32}$ P-labelled M13 DNA to DNA from $B$. thuringiensis subsp. thuringiensis serotype 1 (strains B and Berliner), digested with different restriction enzymes under low-stringency conditions $\left(51^{\circ} \mathrm{C}\right)$. Even-numbered lanes, strain $B$; oddnumbered lanes, strain Berliner. Lanes 1 and 2, PstI; lanes 3 and 4, PvuII; lanes 5 and 6, BgIII; lanes 7 and 8, BamHI; lanes 9 and 10 , $P v u \mathrm{II}+$ PstI ; lanes 11 and 12, PvuII + HaeIII.

we compared strain $\mathrm{H} 14$ with an acrystalliferous plasmidless mutant of the same strain designated as H1499. No differences were detected after EcoRI and PstI digestions (data not shown) but the enzyme combination EcoRI + HaeIII yielded specific patterns with some band position differences (Fig. 3, lanes 20 and 21) This observation raises the question whether DNA fingerprinting allows genome differentiation at the strain level or further. More investigations of other mutants will be necessary to answer this question.

\section{Comparison among serotypes}

As shown above, the variations between strains within the same serotype were sometimes quite significant. This made difficult not only the comparison of such strains but also that of the serotypes. For most of the strains belonging to different serotypes, DNA digested with the same enzyme possessed one or more common bands, sometimes more intense than the other bands in the profile. This was better observed in single enzyme digestions (Fig. 4). Since cleavage was always performed to completion with excess enzyme, the appearance of these strong bands could be due to the presence of species-specific sequences containing multiple copies of M13 repeats. The strain representing serotype 2 was an interesting exception, also displaying an intense band but of smaller size (Fig. 4, lane 22). Very low $D$ values were obtained when this strain was compared to strains from other serotypes (Table 4). Serotype 2 of $B$. 

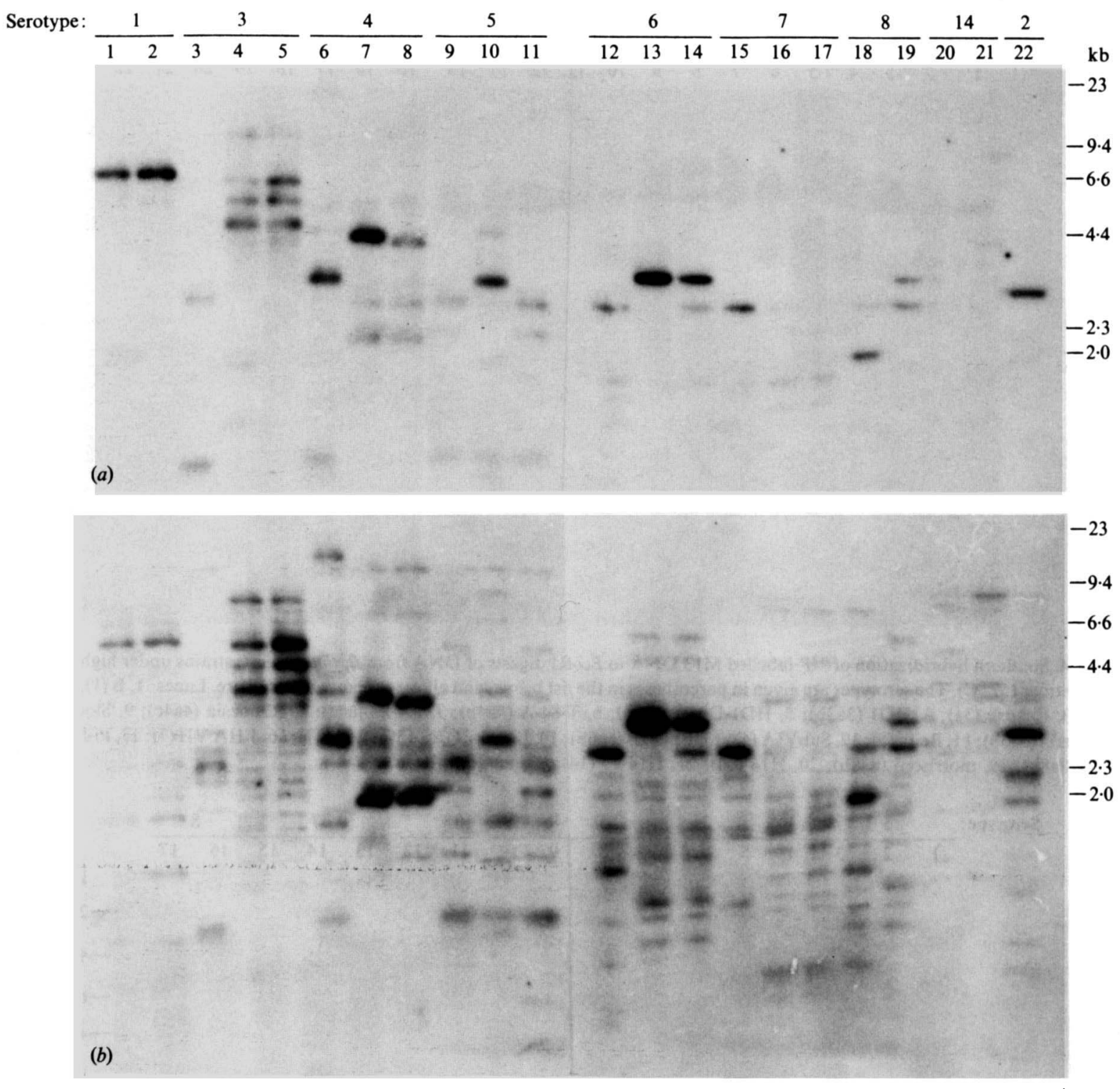

Fig. 3. Southern hybridization of ${ }^{32} \mathrm{P}-$ labelled M13 DNA to EcoRI + HaeIII digests of DNA from $B$. thuringiensis strains at two different stringencies. (a) Temperature of hybridization and washing $57^{\circ} \mathrm{C}$. (b) The same nitrocellulose filter was reprobed at $51^{\circ} \mathrm{C}$. The restriction conditions and the probe were the same as in Fig. 1. The serotypes are given in parentheses in the list below and above the lanes in the figure. Lanes: 1, B (1); 2, Berliner (1); 3, Euxoae (3a); 4, HDl (3a3b); 5, HD1-Dipel (3a3b); 6, T-84-A (4a4b); 7, S-4-2 (4a4c); 8, Rhodesia (4a4c); 9, Slough (5); 10, Galleria (5a5b); 11, Beira (5); 12, SubVIA (6); 13, EntVIB (6a6b); 14, Limassol (6); 15, aiVII3 (7); 16, 1 HA VII (7); 17, Pill 122 (7); 18, 8m (8a8b); 19, morrisoni (8a8b); 20, H14 (14); 21, H14-99 (14); 22, fin-2 (2).

thuringiensis is unique in its ability to form the parasporal inclusion inside and not outside the exosporium.

The patterns for serotypes 4,5 and 7 obtained after digestion with $X b a I$ contained a small number of fragments with minor differences in their size (Fig. 5). Similar results were obtained with other single enzyme digestions.

The picture changed when double digestions were performed. This resulted in a larger number of bands, generating unique patterns that still showed common bands (Fig. 3). To gain more information, several double digestions were analysed, including typical strains from each serotype (Fig. 3b). One strain typical for each serotype was chosen among the highly similar pairs. These representative strains were compared pairwise. The results presented in Table 4 show that the strains from different serotypes displayed a marked degree of polymorphism, giving relatively low similarity indexes. At the same time serotypes 3 and 7,3 and 8,5 and 7, and 7 and 8 possessed very similar patterns $(D 0.71-0.75)$. These values were higher than those obtained when strains from the same serotype were compared. This 
Serotype:

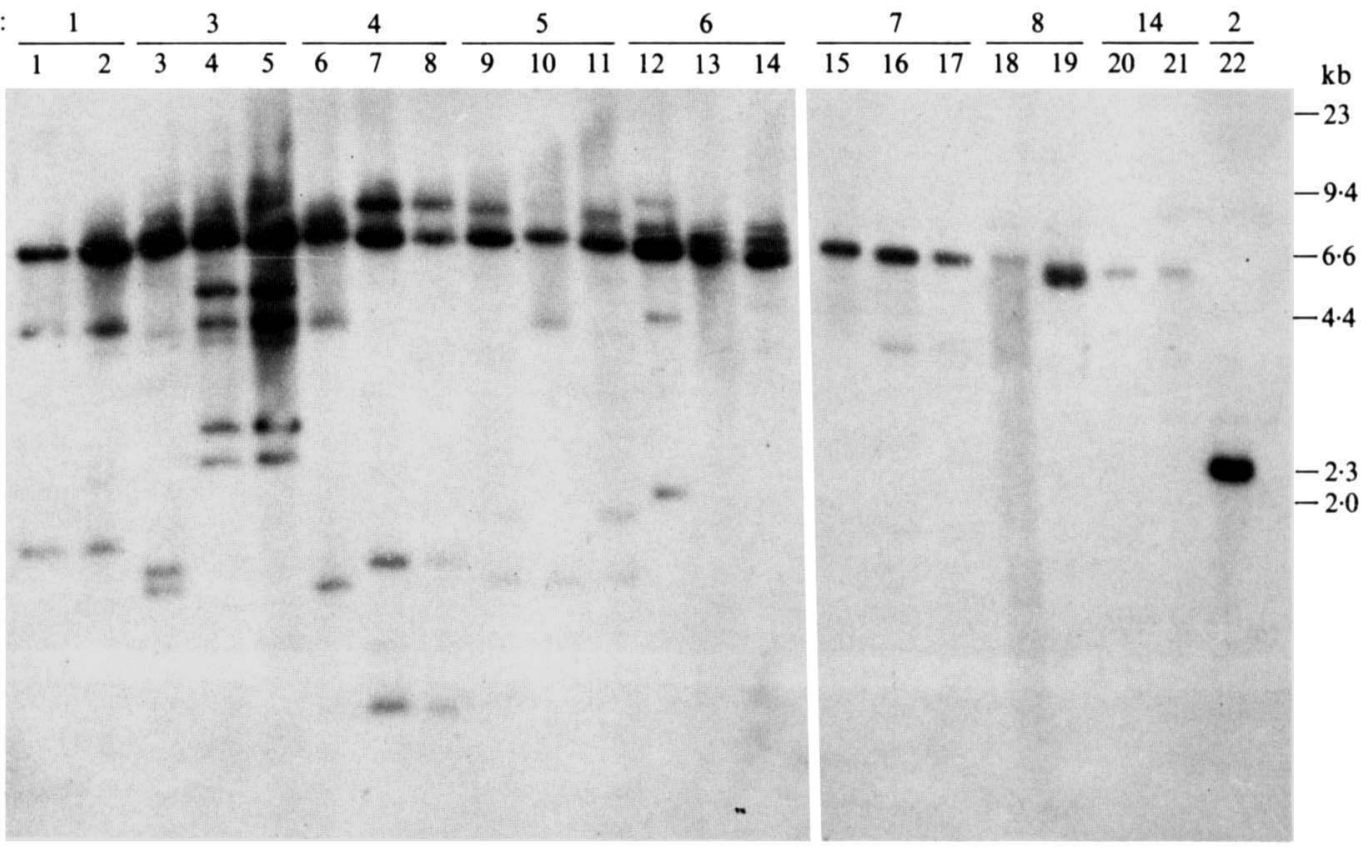

Fig. 4. Southern hybridization of ${ }^{32} \mathrm{P}$-labelled M13 DNA to EcoRI digests of DNA from $B$. thuringiensis strains under high-stringency conditions $\left(57^{\circ} \mathrm{C}\right)$. The serotypes are given in parentheses in the list below, and above the lanes in the figure. Lanes: 1, B (1);2, Berliner (1); 3, Euxoae (3a); 4, HD1 (3a3b); 5, HD1-Dipel (3a3b); 6, T-84-A (4a4b); 7, S-4-2 (4a4c); 8, Rhodesia (4a4c); 9, Slough (5); 10, Galleria (5a5b); 11, Beira (5); 12, SubVIA (6); 13, EntVIB (6a6b); 14, Limassol (6); 15, ai-VII3 (7); 16, 1 HA VII (7); 17, Pill 122 (7); 18, 8m (8a8b); 19, morrisoni (8a8b); 20, H14 (14); 21, H14-99 (14); 22, fin-2 (2).

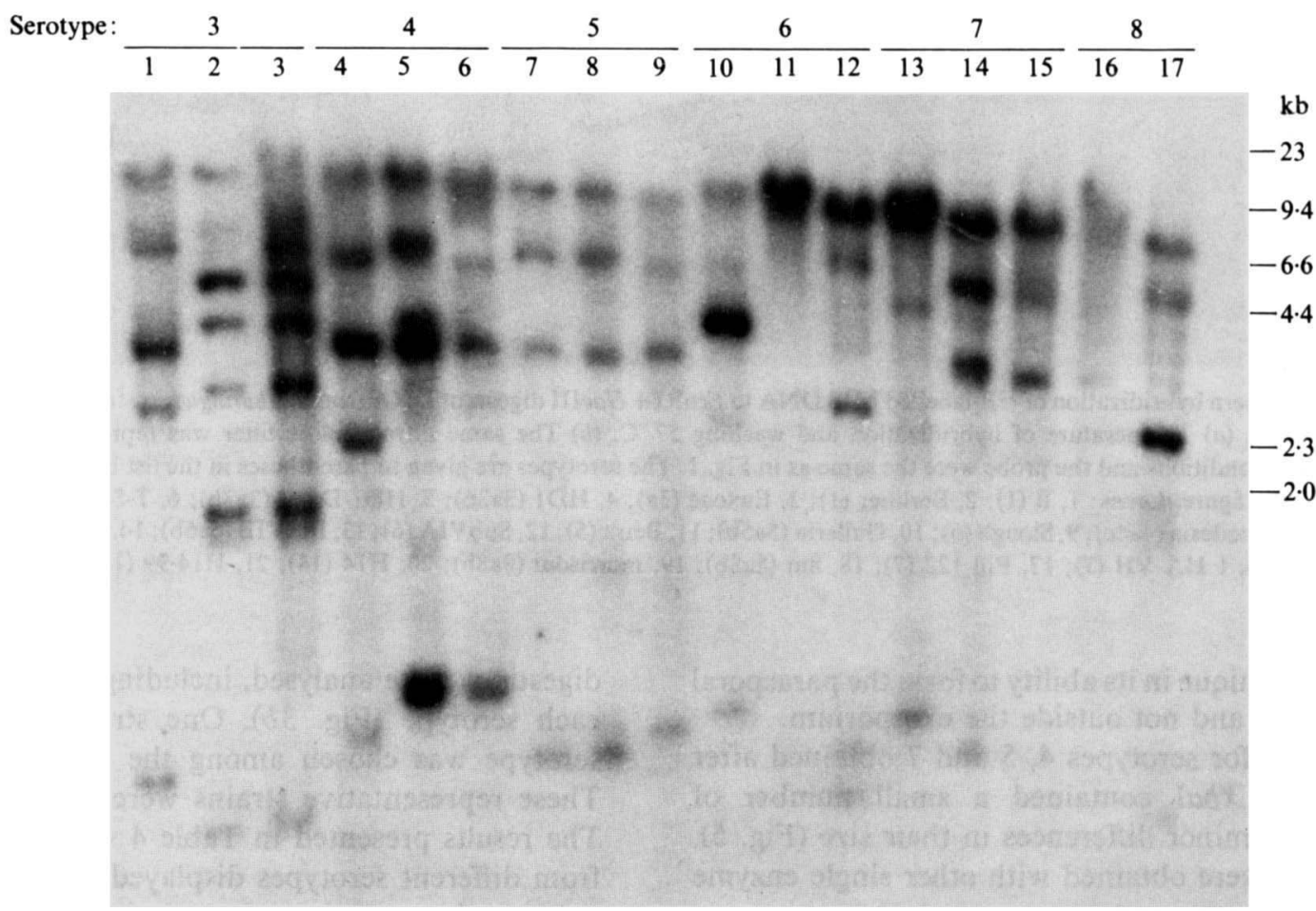

Fig. 5. Southern hybridization of ${ }^{32} \mathrm{P}$-labelled DNA to $\mathrm{XbaI}$ digests of DNA from $B$. thuringiensis strains under low-stringency conditions $\left(51^{\circ} \mathrm{C}\right)$. The serotypes are given in parentheses in the list below, and above the lanes in the figure. Lanes: 1, Euxoae (3a); 2 , HD1 (3a3b); 3, HD1-Dipel (3a3b); 4, T-84-A (4a4b); 5, S-4-2 (4a4c); 6, Rhodesia (4a4c); 7, Slough (5); 8, Galleria (5a5b); 9, Beira (5); 10, SubVIA (6); 11, EntVIB (6a6b); 12, Limassol (6); 13, ai-VII3 (7); 14, 1 HA VII (7); 15, Pill 122 (7); 16, 8m (8a8b); 17, morrisoni (8a8b). 
Table 3. Similarity indexes of all pairwise comparisons of $B$. thuringiensis strains within the serotypes

\begin{tabular}{|c|c|c|c|c|}
\hline \multirow{2}{*}{$\begin{array}{c}\text { Serotype/ } \\
\text { no. of strains }\end{array}$} & \multicolumn{4}{|c|}{ 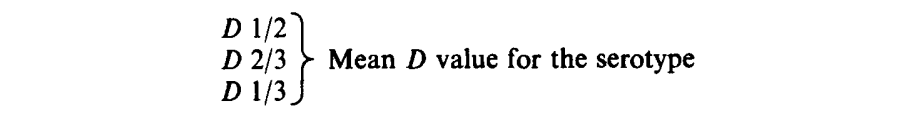 } \\
\hline & $E c o \mathrm{RI}$ & $X b a I$ & $E c o \mathrm{RI}+P s t \mathrm{I}$ & EcoRI + HaeIII \\
\hline $1 / 2^{*}$ & $\begin{array}{l}1.00 \\
0.11\end{array}$ & $0.237^{-}$ & $\begin{array}{l}0.94 \\
0.28\end{array}$ & $\begin{array}{l}0.93 \\
0.21\end{array}$ \\
\hline $3 / 3$ & $\left.\begin{array}{l}1.00 \\
0.11\end{array}\right\} 0.41$ & $\left.\begin{array}{l}0.77 \\
0.55\end{array}\right\} 0.52$ & $\left.\begin{array}{l}0.86 \\
0.20\end{array}\right\} 0.45$ & $\left.\begin{array}{l}0.93 \\
0.21\end{array}\right\} 0.45$ \\
\hline $4 / 3$ & $\left.\begin{array}{l}0.55 \\
0.82 \\
0.59\end{array}\right\} 0.65$ & $\left.\begin{array}{l}0 \cdot 23 \\
0 \cdot 59 \\
0 \cdot 44\end{array}\right\} 0 \cdot 42$ & $\left.\begin{array}{l}0.58 \\
0.83 \\
0.33\end{array}\right\} 0.58$ & $\left.\begin{array}{l}0.36 \\
0.87 \\
0.48\end{array}\right\} 0.57$ \\
\hline $5 / 3$ & $\left.\begin{array}{l}0.36 \\
0.44 \\
0.83\end{array}\right\} 0.54$ & $\left.\begin{array}{l}0.72 \\
0.40 \\
0.83\end{array}\right\} 0.64$ & $\left.\begin{array}{l}0.47 \\
0.25 \\
0.95\end{array}\right\} 0.56$ & $\left.\begin{array}{l}0.54 \\
0.44 \\
0.92\end{array}\right\} 0.62$ \\
\hline $6 / 3$ & $\left.\begin{array}{l}0.35 \\
0.90 \\
0.33\end{array}\right\} 0.53$ & $\left.\begin{array}{l}0.22 \\
0.31 \\
0.19\end{array}\right\} 0.24$ & $\left.\begin{array}{l}0.31 \\
0.67 \\
0.31\end{array}\right\} 0.43$ & $\left.\begin{array}{l}0.30 \\
0.92 \\
0.35\end{array}\right\} 0.53$ \\
\hline $7 / 3$ & $\left.\begin{array}{l}0.26 \\
0.67 \\
0.30\end{array}\right\} 0.52$ & $\left.\begin{array}{l}0.20 \\
0.67 \\
0.14\end{array}\right\} 0.34$ & $\left.\begin{array}{l}0.26 \\
0.83 \\
0.23\end{array}\right\} 0.44$ & $\left.\begin{array}{l}0.51 \\
0.90 \\
0.57\end{array}\right\} 0.66$ \\
\hline $8 / 2$ & 0.38 & 0.50 & 0.48 & $0 \cdot 61$ \\
\hline $14 / 2$ & 1.00 & - & 1.00 & 0.79 \\
\hline
\end{tabular}

* The two strains from serotype 1 were studied with more restriction enzymes. The $D$ values for pairwise comparison of these strains were: PstI, 0.93; PvuII, 0.92; BglII, 0.87; BamHI, 0.75; PvuII + HaeIII, 0.90; PvuII + PstI, 0.90 (mean value for serotype, 0.88).

Table 4. Similarity among serotypes of $B$. thuringiensis

Pairwise comparisons were made for all possible pairs among the patterns of eight strains, each representing one serotype (Fig. $3 b$ ).

\begin{tabular}{|c|c|c|c|c|c|c|c|c|}
\hline \multirow[b]{2}{*}{ Serotype } & \multicolumn{8}{|c|}{ Index of similarity $(D)$} \\
\hline & 2 & 3 & 4 & 5 & 6 & 7 & 8 & 14 \\
\hline 1 & $0 \cdot 40$ & 0.44 & 0.44 & 0.50 & 0.34 & 0.52 & $0 \cdot 50$ & 0.55 \\
\hline 2 & & 0.44 & 0.22 & $0 \cdot 20$ & 0.18 & 0.44 & 0.25 & 0.33 \\
\hline 3 & & & 0.32 & $0 \cdot 30$ & 0.49 & 0.74 & 0.75 & 0.40 \\
\hline 4 & & & & 0.55 & 0.40 & $0 \cdot 32$ & 0.27 & 0.25 \\
\hline 5 & & & & & 0.36 & 0.74 & 0.42 & 0.55 \\
\hline 6 & & & & & & 0.48 & 0.54 & 0.20 \\
\hline 7 & & & & & & & 0.71 & 0.32 \\
\hline 8 & & & & & & & & 0.54 \\
\hline
\end{tabular}

provides further evidence that the division of $B$. thuringiensis strains into serotypes does not always adequately reflect their genetic relatedness.

Several factors have played an important role in the genetic divergence of $B$. thuringiensis, such as the presence of many different plasmids in each strain, the conjugation transfer mechanism and the transposon-like inverted repeats flanking the endotoxin genes (Aronson et al., 1986). These considerations could help to explain the large variations in this species on the basis of a high frequency of DNA rearrangements.

Although the data presented here involve only a few strains from several serotypes, the general conclusion can be made that DNA fingerprinting has a very high resolution, making it possible to differentiate between individual strains of $B$. thuringiensis. The results are encouraging for a future application of hypervariable minisatellite analysis as a rapid and reliable tool for 
confirmation of $B$. thuringiensis strain identity on the basis of a unique pattern of the whole genome. This approach, together with other techniques of molecular biology, could contribute to the establishment of a new classification scheme for $B$. thuringiensis. It could also add to the precision of numerical taxonomic analysis of this and other Bacillus species.

This investigation received financial support from the UNDP/ World Bank/WHO Special Programme for Research and Training in Tropical Diseases (TDR).

\section{References}

Aronson, A. I., Beckman, W.\& DunN, P. (1986). Bacillus thuringiensis and related insect pathogens. Microbiological Reviews 50, 1-24.

DE BARJAC, H. \& BonNEFol, A. (1973). Classification of Bacillus thuringiensis. Entomophaga 18, 5-17.

Grigorova, R. T. (1964). Deux souches de Bacillus thuringiensis Berliner isolées des chenilles du Bombyx disparate Limantria dispar. Entomophaga, mem. hors serie 2, 179-191.

JefFreys, A., WiLson, V. \& TheIN, S. (1985). Individual specific 'fingerprints' of human DNA. Nature, London 316, 76-79.

Kaneko, T., Nozaki, R. \& AizaWa, K. (1978). Deoxyribonucleic acid relatedness between Bacillus anthracis, Bacillus cereus and Bacillus thuringiensis. Microbiology and Immunology 22, 639-641.

Kronstad, J. W., SChNEPF, H. E. \& Whiteley, H. E. (1983). Diversity of locations for Bacillus thuringiensis crystal protein genes. Journal of Bacteriology 154, 419-428.

KRYWIENCZYK, J. (1977). Antigenic composition of $\delta$-endotoxin as an aid in identification of Bacillus thuringiensis varieties. Technical Report, Canadian Forestry Service no. IP-X-16.
LUTHY, P. (1986). Insect pathogenic bacteria as pest control agents. In Fortschritte der Zoologie, vol. 32, Biological Plant and Health Protection, pp. 201-216. Edited by X. Franz. Stuttgart \& New York: G. Fischer.

Miteva, V. I., Grigorova, R. T. \& Valcheva, Tz. I. (1986). Plasmids and crystal toxin production in Bacillus thuringiensis subsp. israelensis. Acta Microbiologica Bulgarica 19, 23-26.

Miteva, V. I., Abadjieva, A. N., Ivanov, P. L. \& Grigorova, R. T. (1990). M13 bacteriophage DNA as a probe for DNA fingerprinting in Gram-positive microorganisms. Systematic and Applied Microbiology 13, 350-353.

NyBOM, H., Rogstad, S. H. \& SCHAAL, B. A. (1990). Genetic variation detected by use of the M13 DNA fingerprinting probe in Malus, Prunus and Rubus (Rosaceae). Theoretical and Applied Genetics 79, 153-156.

Prefontaine, G., Fast, P., LaU, P. C. K., Hefford, M. A., Hanna, $Z$. \& Brouseau, R. (1987). Use of oligonucleotide probes to study the relatedness of delta-endotoxin genes among Bacillus thuringiensis, subspecies and strains. Applied and Environmental Microbiology 53, 2808-2814.

Priest, F. G., Goodfellow, M. \& Todd, C. (1988). A numerical classification of the genus Bacillus. Journal of General Microbiology 134, 1847-1882.

Ryskov, A. P., Jincharadze, A. G., Prosnyak, M. I., Ivanov, P. L. \& LiMBORSKA, S. A. (1988). M13 phage DNA as an universal marker for DNA fingerprinting of animals, plants and microorganisms. FEBS Letters 233, 388-392.

SOMER VILLE, H. J. \& JONES, M. I. (1972). DNA competition studies within the Bacillus cereus group of bacilli. Journal of Molecular Biology 73, 257-265.

SOUTHERN, E. M. (1975). Detection of specific sequences among DNA fragments separated by gel electrophoresis. Journal of Molecular Biology 98, 503-517.

Vassart, G., Georges, M., Monsieur, R., Brocas, H., Lequarre, A. S. \& Christophe, D. (1987). A sequence in M13 phage detects hypervariable minisatellites in human and animal DNA. Science Reports 235, 683-685. 